Discussion Paper No. 06-012

\title{
The Drivers of Deregulation in the Era of Globalization
}

Friedrich Heinemann

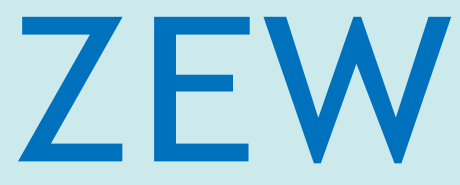

Zentrum für Europäische Wirtschaftsforschung $\mathrm{GmbH}$

Centre for European

Economic Research 
Discussion Paper No. 06-012

\title{
The Drivers of Deregulation in the Era of Globalization
}

\author{
Friedrich Heinemann
}

Download this ZEW Discussion Paper from our ftp server:

ftp://ftp.zew.de/pub/zew-docs/dp/dp06012.pdf

Die Discussion Papers dienen einer möglichst schnellen Verbreitung von neueren Forschungsarbeiten des ZEW. Die Beiträge liegen in alleiniger Verantwortung der Autoren und stellen nicht notwendigerweise die Meinung des ZEW dar.

Discussion Papers are intended to make results of ZEW research promptly available to other economists in order to encourage discussion and suggestions for revisions. The authors are solely responsible for the contents which do not necessarily represent the opinion of the ZEW. 


\section{Non-Technical Summary}

The last two decades have not only been an era of increasing international mobility of goods, services and factors but also one of a decreasing regulatory burden in a number of markets. Given these parallel trends the question on the nature of this correlation arises: Is it a mere coincidence or does it represent some kind of causal link between globalization and deregulation?

This analysis intends to provide for a better understanding of these issues through a thorough empirical analysis on the basis of an OECD country panel for the period 1975 until 2000. The study is also to contribute to the small but growing empirical literature on the determinants of structural reforms. Regulatory change is a particular sub-type of structural reform which can also target at, e.g., the monetary regime, the tax system or the size and structure of the government sector. This literature has been motivated by desire to explain why industrial countries show very different speeds of adjusting their structures to new circumstances which are related to increasing global competition but also to internal changes resulting from the demographic change.

The empirical analysis makes use of recently collected regulation indicators for four policy fields: financial market, product markets, labour markets and trade. After a short discussion of the link between globalization and deregulation and a descriptive view at the correlations, a panel analysis for OECD countries for the period 1975 to 2001 is executed. The evidence shows that globalization in the narrow sense of trade openness and capital mobility has a rather limited impact as an immediate driver of deregulation. However, in a wider sense globalization definitions also comprise the easier flow of knowledge and information across borders resulting in more effective cross-border learning processes.

The results hint to the empirical relevance of these cross-border learning aspects of globalization at least on fields like product and financial markets. Labour market 
regulation is a notable exception: Here, neither deregulation nor convergence nor cross-border learning has taken place in the covered period. The findings on labour market regulation are compatible with the compensation hypothesis: Globalization may have increased the political-economic demand for job insider protection and unemployment benefits. 


\title{
The Drivers of Deregulation in the Era of Globalization
}

\author{
Friedrich Heinemann \\ Centre for European Economic Research (ZEW) \\ March 2006 \\ Forthcoming in: \\ Peter Bernholz and Roland Vaubel (Edts.): \\ Political Competition and Economic Regulation, 2006.
}

\begin{abstract}
This paper treats the question to what extent globalization trends restrict a countryspecific regulation policy in industrial countries. The empirical analysis makes use of recently collected regulation indicators for four policy fields: financial market, product markets, labour markets and trade. After a short discussion of the link between globalization and deregulation and a descriptive view at the correlations, a panel analysis for OECD countries for the period 1975 to 2001 is executed. The evidence shows that globalization in the narrow sense of trade openness and capital mobility has a rather limited impact as an immediate driver of deregulation. However, in a wider sense globalization definitions also comprise the easier flow of knowledge and information across borders resulting in more effective cross-border learning processes.
\end{abstract}

Acknowledgement: I thank Thomas Helbling, IMF, for kindly providing me with the regulation indicators.

JEL-Classification: E 63, H00

Keywords: economic policy reforms, structural reforms, regulation

P.O. Box 103443

68034 Mannheim

Germany
Phone +496211235 149

Fax +496211235223

Email_heinemann@zew.de 


\section{Introduction}

The last two decades have not only been an era of increasing international mobility of goods, services and factors but also one of decreasing regulatory burden in a number of markets. Given these parallel trends the question on the nature of this correlation arises: Is it a mere coincidence or does it represent some kind of causal link between globalization and deregulation? Of course, for certain interdependencies the answer is trivial: Deregulation of international transactions directly causes or at least amplifies globalization trends. However, the opposite causal link from globalization towards regulatory decisions is less straightforward. It is not clear a priori, whether, how and to which extent increasing cross-border factor mobility will impact on regulatory equilibria - be it on the fields of labour, financial market, trade or product regulation.

Thus, the guiding question of this study is to which extent globalization limits the national leeway for country-specific regulatory solutions. This issue is a neglected dimension of the globalization debate. Compared to fiscal policy in general (see Vaubel, 2005, for a recent update of references) and tax policy in particular (see the survey of Schulze and Ursprung, 1999) the issue of regulatory sovereignty in a globalising environment has attracted much less attention in the academic literature. This may be partially explainable from data reasons since it is more difficult to quantify regulatory changes compared to changes in government expenditures or revenues. However, conceptually both fields are closely connected: Both explicit transfers through government spending and implicit transfers through regulation may serve the same political-economic purpose of favouring specific interest groups. In this sense, government spending and regulation can be substitutes. Therefore, it is equally desirable to study the consequences of increasing factor mobility for government activity both on the fiscal and the regulatory field.

This analysis intends to provide for a better understanding of these issues through a thorough empirical analysis on the basis of an OECD country panel for the period 1975 until 2000. The study is also to contribute to the small but growing empirical literature on the determinants of structural reforms. Regulatory change is a particular sub-type of structural reform which can also target at, e.g., the monetary regime, the tax system or the size and structure of the government sector. This literature has been motivated by desire to explain why industrial countries show very different speeds of adjusting their structures to new circumstances which are related to increasing global competition but also to internal changes resulting from the demographic change.

In the literature on structural reforms, case studies with a focus on developing countries used to dominate (see Rodrik, 1996 for a by now somewhat out-dated survey of this literature). Examples for more recent and more comprising panel analyses are Pitlik and Wirth (2003) and Heinemann (2004) who make use of economic freedom 
indicators as proxies for structural change and analyze the relevant drivers for large global country panels. In their panel analysis for 35 countries, Abiad and Mody (2003) focus on financial market deregulation and, therefore, are already closer to the regulation focus. The authors find a positive impact of trade openness on the pace of deregulation. Although some robust results originate from these studies - for example, the fact that deep economic crises tend to increase the likelihood of structural reforms -, they do not account for the enormous economic and political heterogeneity among countries of very different income classes and constitutional situations and, therefore, are only of limited use to learn much about the drivers of deregulation in industrial and democratic countries.

An analysis more concentrated both on the conditions in industrial countries and deregulation is Helbling et al. (2004) whose approach is followed here both with regard to the underlying data set and the basic model. In particular, we use the same time series on four regulatory fields: regulation of financial markets, product markets, labour markets and international trade. However, our study addresses the shortcomings of Helbling et al. (2004) which - in the light of our guiding question - is the rather simple approximation of the globalization trend by the trade openness variable which only measures one dimension of increasing internationalisation and neglects both capital and labour mobility. Furthermore, among the institutional variables this study does not take account of a possible impact of internal domestic political competition related to federalism.

The study proceeds in the following way: In section 2, we summarize a number of theoretical arguments relevant for the impact of globalization on regulation. In section 3, a brief descriptive glance at our regulatory indicators and globalization measures is presented. Section 4 presents our model specification and panel regressions followed by the conclusions.

\section{Globalization and regulation - an overview of arguments and determinants}

Depending on the regulatory context there are very different and often counteracting arguments how globalization should influence regulation.

The diversity of arguments originates from the fact that both globalization and regulation have many facets. In its narrow economic definition, "globalization" describes the trend that national borders tend to lose their significance as a relevant obstacle to economic transactions or - more technically speaking - the occurrence of "a reduction in international arbitrage costs" (Schulze and Ursprung, 1999, p. 301). However, there are additional aspects related to the exchange of information and the degree of political competition. The costs of voters getting informed about the conditions beyond their home countries' borders through the media or to physical travel- 
ling have come down - a fact which could contribute to an intensification of the yardstick competition phenomenon (Besley and Case, 1995) according to which the performance of a government is assessed relative to the performance of some (neighbouring) benchmark.

It is helpful to organize the relevant arguments in the logic of the Stigler-Peltzman model of regulation (see Mueller, 1989, for a survey). Politicians with regulative power face a trade-off: Increasing, e.g., regulated prices they win political support from the benefiting companies whereas they lose support from consumers. This trade-off between the interests of winners and loser of regulation is a typical feature independent of the specific regulatory context. Consequently, given the vote maximisation hypothesis, a political-economic equilibrium results where marginal gains in votes are equilibrated to marginal losses. The equilibria depend on many features of policy field such as: the existence of well-organised interest groups representing winners and/or losers, their voting and campaign financing power, the extent, distribution and perceptibility of regulation costs and benefits, the level of voters' information or external restrictions.

All these features can be influenced by increasing globalization rendering the closed country regulation equilibrium instable. The following arguments hint towards the deregulative power of globalization:

- The media dimension of globalization, but also people's increasing professional or holiday mobility make it easier for voters to learn from comparisons with other countries about the costs of regulation. This increases the relative power of those who usually pay the price of regulation without being fully aware of this due to regulation's intransparent character. In this sense, globalization should improve the pre-conditions for cross-border learning.

- The political benefits of regulation which lays the burden on increasingly mobile factors like capital (or high-income individuals) tend to shrink. In the extreme, mobility might simply render certain regulations ineffective - a phenomenon relevant for some types of financial market regulation (for example, interest rate regulation would no longer be effective given the degree of financial capital mobility on current financial markets).

- The beneficiaries of regulation at product markets which are, on the national level, often homogeneous, limited in number and therefore capable of organising their interests according to Olson's (1965) theory of interest groups, might not be able to organize internationally. Thus, they would not be able to establish a similar political power on an international level even if on this level political suppliers of regulation exist - as it is the case for the European Union. On the national level, producer groups that used to have significant political in- 
fluence in a protected market might lose this influence once foreign producers enter the market and start to articulate their differential interests.

However, globalization might not necessarily work exclusively towards deregulation. Under certain conditions it might increase the benefit of specific types of regulation and then even lead to new regulative initiatives. This is the case if increasing factor mobility creates new risks for the economy as a whole or at least for an influential interest group.

This could be particularly relevant in the context of labour market regulation. On the one hand, increasing capital mobility puts inefficient solutions under pressure through raising structural unemployment in heavily regulated labour markets as it is notoriously the case for labour markets in the larger continental European countries. In this sense, globalization has increased the marginal costs of labour market regulation and pushes towards deregulation.

On the other hand, the political marginal benefit of labour market regulation might increase if globalization increases business cycle volatility and/or structural change inducing job insiders to demand a larger level of job protection as a compensation for accepting trade liberalization. This reasoning is analogous to the debate on the link between globalization and the size of government and social spending. Rodrik has postulated the compensation hypothesis according to which increasing social spending is the price that has to be paid to make voters accept internationalisation of their economies (Rodrik 1998, see Vaubel (2000) for a survey on the literature and an empirical assessment).

Recently, Vaubel (2005) has proposed an alternative to Rodrik's compensation hypothesis with fundamentally different policy conclusions: He argues that the correlation between openness and social spending is not the outcome of an ex ante compensation deal but reflects the following chain of causality: Countries with inflexible labour markets experience an increase in structural unemployment with increasing openness. Subsequently, governments use part of the welfare gains of increasing international trade to extend social spending. With this perspective, a compensation of labour is not a necessary precondition to buy acceptance for globalization but rather reflects the inability of some countries to increase labour market flexibility.

Regulatory implicit transfers can be a substitute for explicit fiscal transfers. Hence, whatever the true structures behind the link between social spending and augmented cross-border trade, they point to the fact that at least in the case of labour market regulation there can be countervailing forces pressing for even more regulation with globalization.

Assessing the impact of globalization on regulation should take account of further mechanism driving the acceptability of structural reforms (see Heinemann, 2004, 
and Helbling et al, 2004). One insight from this literature is that a shock which forces the modest adjustment of the institutional status quo in the first step can be a trigger of more fundamental change. The "status quo bias" is empirically well proven in behavioural economics experiments: It describes a situation where people have a preference for one option among many others only because this option happens to be the status quo (Samuelson and Zeckhauser, 1988). If a minor change occurs this specific option loses attraction immediately. The implication for reforms is that a small shock could overcome psychological resistance to more radical changes since it opens the way for a less biased reflection on optimum institutional solutions.

This argument of small initial changes followed by speeding up more far-reaching deregulation can also be based on learning about the true distributional consequences of deregulation. The pre-reform unknown identity of winners and losers of institutional change is one of the classical explanations for resistance to welfare improving reforms (Fernandez and Rodrik, 1991). Even small first deregulation steps might help to identify the winners and losers and thus contribute to reduce uncertainty (Abiad and Mody, 2003). If this turns out to be empirical relevant, small steps matter and deregulation can be self-accelerating.

The phenomenon of the status quo bias is also closely linked to the observation that crisis often appears to be a pre-condition for reforms. A general feeling of crisis can open the window of opportunity for change since the status quo is then regarded as being non-sustainable. Globalization pressure can contribute to this sense of crisis.

The literature on determinants of structural reforms cited above hints to the following further economic and political determinants which can be relevant for structural changes in general and the speed of deregulation in particular:

- General economic conditions: In line with the crisis hypothesis, the general economic situation measured on the basis of standard variables like growth, budget deficits, inflation or unemployment should matter with bad data increasing the likelihood of deregulation.

- Ideology: Governments of different ideologies typically also have different views at the desirable extent of regulatory involvement. These views should influence outcomes only if globalization leaves any leeway. In this sense, testing the relevance of ideology is also a test with regard to the political leeway that remains under globalization.

- Decentralization of government: Internal competition between autonomous regions could accelerate structural adjustments.

- Strength of governments: A strong and stable government should be better able to carry out reforms. 
- Election cycle: Post election years are often windows of opportunity for institutional change - due to the relatively long time horizon the newly elected (or reelected) government faces. Government being newly elected regularly are in an ever better position for larger changes due to the "honeymoon effect", an initial bonus of confidence, the fresh government normally experiences in the polls.

- External restrictions: EU, IMF or WTO membership offer examples of external restrictions a country can face defining its regulatory policies. In an empirical study on OECD countries only the EU dummy offers sufficient cross-section variability for testing.

\section{Regulation and globalization: the experience since the mid- seventies}

Our time series on the restrictiveness on government regulation of trade and of product, labour and financial markets originate from the data collection used in the World Economic Outlook (WEO) 2004 (Helbling et al., 2004, Appendix 3.1. for details on sources and construction). The 21 OECD countries covered are: Australia, Austria, Belgium, Canada, Denmark, Finland, France, Germany, Ireland, Italy, Japan, Netherlands, New Zealand, Norway, Portugal, Spain, Sweden, Switzerland, United Kingdom and United States (in the econometric analysis, Japan and Greece drop out due to missing control variables). The time series start in 1975 and, currently, extent to 1998 for labour and product markets, to 2001 for financial markets and to 2002 for trade.

All indicators are normalized to range from 0 to 1 where an increasing value signals a declining degree of restriction. The first three indicators are calculated as an unweighted average of sector-specific indicators depicting different dimension of regulatory intervention.

The regulation indicator for the financial sector (WEOFINANCIAL) takes account of the existence of credit controls, interest rate controls and restrictions on international financial transactions. Thus, this indicator does not include regulatory issues linked to reporting and financial stability oriented monitoring of the financial sector which, certainly, would show very different time trends.

The labour market indicator (WEOLABOR) is constructed on the basis of the Labor Market Institutions Database developed by Nickel and Nunziata (2001) and is the aggregate of sub-indicators on employment protection, benefit replacement rates and benefit duration. It excludes information on wage centralization since, for numerous countries, there is no time variance for related variables. 
The product market indicator (WEOPRODUCT) was constructed by Nicoletti and Scarpetta (2003) and combines indicators on barriers to entry, public ownership, market structure, vertical integration of networks and final consumer services, and price controls for the following non-manufacturing sectors: gas, electricity, post, telecommunications, passenger air transport, railways and road freights. It thus covers the sectors which used to be characterised by heavy government involvement and protected monopolies/oligopolies in the past.

Finally, the trade related indicator (WEOTRADE) is constructed on the basis of effective tariffs relating revenues from customs and import duties to the value of imports. It should be noted that this indicator does not account for non-tariff obstacles to trade.

Figure 1 summarizes the cross-section distribution of these indicators over time. ${ }^{1}$ The first striking observation is that the labour market regulation trend differs fundamentally from the other markets. Whereas the years between 1975 and the end of the nineties have brought massive dismantling of regulatory limitations for financial transactions, activities on formerly protected service markets and obstacles to crossborder trade, the same period is characterised by an initial increase of regulatory standards on labour markets and stagnation in the later years.

Clear differences are observable among the deregulation fields, too. Product market deregulation took off later compared to financial and trade deregulation. As a consequence product markets are still distant from being fully liberalised towards the end of the covered period. Cross-country convergence occurred most clearly for financial and trade regulatory standards where industrial countries in the light of the employed indictors have almost completely and jointly overcome regulatory obstacles.

1 Note that, on the basis of the Economic Freedom of the World Indicator, David Henderson in his subsequent comment arrives at a very similar description of deregulation trends. 
Figure 1: Regulation indicators selected OECD countries

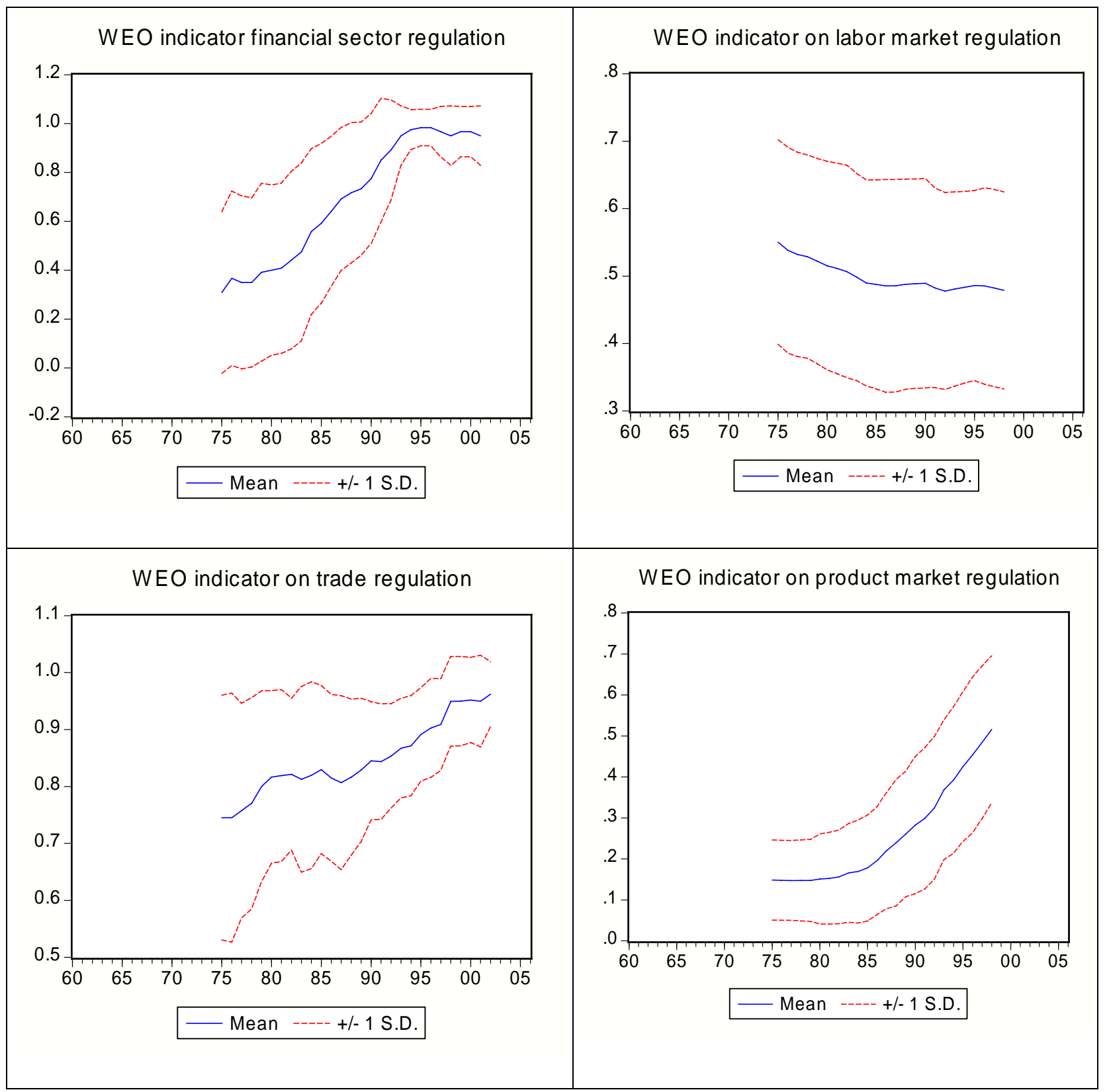

Data source: Helbling et al. (2004), included are the OECD countries as listed at beginning of section 3.

Turning now to the measurement of globalization we focus on measures for mobility of goods, services, capital and people. Figure 2 depicts the time series (the first three in \% of GDP) for trade openness (sum of exports and imports of goods and services), the gross private capital flows (sum of the absolute values of direct, portfolio, and other investment inflows and outflows), foreign direct investment on its own (which is also included in the former) and finally as a very rough proxy for the mobility of people: the share of foreign population in total population (sources for all globalization measures: the World Bank's World Development Indicators). The share of foreign population variable does not offer full time series for the common sample for a number of non-European countries. 
Figure 2: Globalization indicators for OECD countries

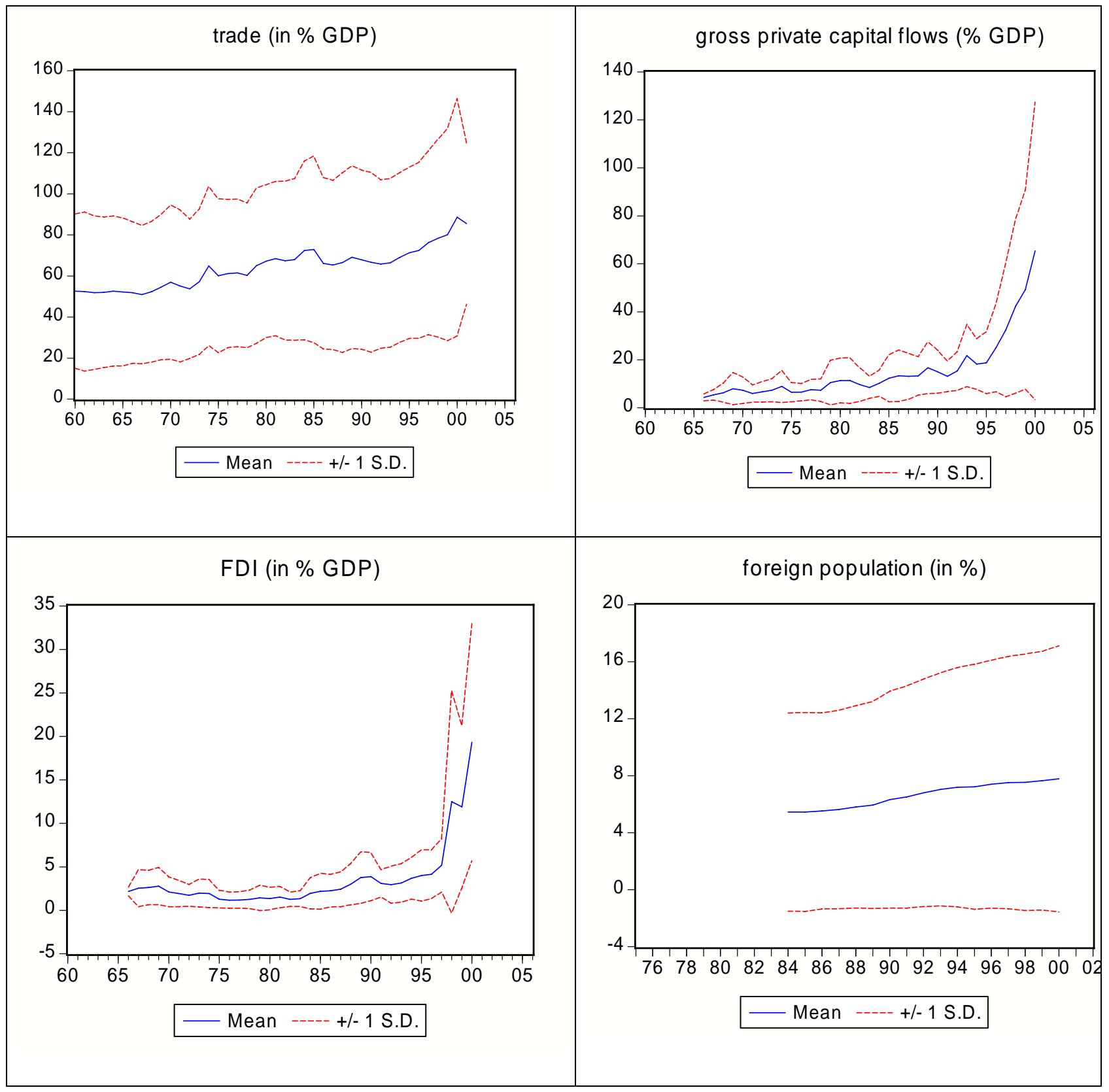

Data source: World Development Indicators, included are the OECD countries as listed at beginning of section 3; smaller coverage for foreign population (no full time series for Australia, Canada, France, New Zealand, Portugal, United States, therefore included from calculation of distribution). 
All four time series show that the decades since the seventies have been an era of a more or less constant increase in cross-border transactions and mobility of people. Acceleration took place after the mid-nineties with strongly increasing mobility of real and financial capital.

While the glance at Figures 1 and 2 justifies the general remark that the period since 1975 has been an era of parallel deregulation and globalization, a more detailed correlation analysis (see Table 1 ) reveals more differentiated insights.

The financial regulation indicator has the least ambiguous correlation profile being significantly positively correlated to all globalization indicators. Labour regulation turns out to be the opposite and a-typical deregulation case since it is negatively correlated to all globalization measures with the exception of foreign population - a finding corresponding to the compensation hypothesis or its variants as discussed above. A further remarkable result is the negative correlation between the product market regulation indicator and trade openness.

A look at the correlation among the different fields of regulation reveals that there is only one significant negative correlation which is the one between labour and trade regulation - a finding which hints toward the possibility that more aggressive protection of job insiders and more generous unemployment benefits are the prices that have to be paid in political-economic bargaining for the impact of trade liberalization on labour markets. 
Table 1: Cross correlations: indicators of regulation and globalization

\begin{tabular}{|c|c|c|c|c|c|c|c|c|c|}
\hline & & WEOFINANCIAL & WEOLABOR & WEOPRODUCT & WEOTRADE & FDI & $\begin{array}{l}\text { FOREIGN } \\
\text { POP. }\end{array}$ & TRADE & $\begin{array}{l}\text { CAPITAL } \\
\text { FLOWS }\end{array}$ \\
\hline \multirow[t]{3}{*}{ WEOFINANCIAL } & Pearson correlation & 1.00 & & & & & & & \\
\hline & two-sided p-value & & & & & & & & \\
\hline & $\mathrm{N}$ & 540 & & & & & & & \\
\hline \multirow[t]{3}{*}{ WEOLABOR } & Pearson correlation & 0.05 & 1.00 & & & & & & \\
\hline & two-sided p-value & 0.24 & & & & & & & \\
\hline & $\mathrm{N}$ & 477 & 477 & & & & & & \\
\hline \multirow[t]{3}{*}{ WEOPRODUCT } & Pearson correlation & 0.55 & 0.28 & 1.00 & & & & & \\
\hline & two-sided p-value & 0.00 & 0.00 & & & & & & \\
\hline & $\mathrm{N}$ & 480 & 477 & 504 & & & & & \\
\hline \multirow[t]{3}{*}{ WEOTRADE } & Pearson correlation & 0.33 & -0.19 & -0.05 & 1.00 & & & & \\
\hline & two-sided p-value & 0.00 & 0.00 & 0.31 & & & & & \\
\hline & $\mathrm{N}$ & 540 & 477 & 480 & 556 & & & & \\
\hline \multirow[t]{3}{*}{ FDI } & Pearson correlation & 0.38 & -0.13 & 0.40 & 0.25 & 1.00 & & & \\
\hline & two-sided p-value & 0.00 & 0.01 & 0.00 & 0.00 & & & & \\
\hline & $\mathrm{N}$ & 500 & 457 & 482 & 500 & 611 & & & \\
\hline \multirow[t]{3}{*}{ FOREIGN POP. } & Pearson correlation & 0.36 & 0.18 & 0.26 & -0.21 & 0.07 & 1.00 & & \\
\hline & two-sided p-value & 0.00 & 0.00 & 0.00 & 0.00 & 0.26 & & & \\
\hline & $\mathrm{N}$ & 276 & 237 & 240 & 276 & 276 & 293 & & \\
\hline \multirow[t]{3}{*}{ TRADE } & Pearson correlation & 0.20 & -0.42 & -0.18 & 0.46 & 0.38 & 0.58 & 1.00 & \\
\hline & two-sided p-value & 0.00 & 0.00 & 0.00 & 0.00 & 0.00 & 0.00 & & \\
\hline & $\mathrm{N}$ & 536 & 477 & 504 & 536 & 611 & 293 & 933 & \\
\hline \multirow[t]{3}{*}{ CAPITAL FLOWS } & Pearson correlation & 0.37 & -0.08 & 0.30 & 0.35 & 0.80 & 0.04 & 0.52 & 1.00 \\
\hline & two-sided p-value & 0.00 & 0.08 & 0.00 & 0.00 & 0.00 & 0.51 & 0.00 & \\
\hline & $\mathrm{N}$ & 512 & 469 & 494 & 512 & 611 & 276 & 623 & 623 \\
\hline
\end{tabular}


Table 2: Cross correlations: indicators of fiscal (revenue) decentralization and regulation

\begin{tabular}{|l|l|r|r|}
\hline & & DRD1 & DRD3 \\
\hline & Pearson correlation & 1 & \\
\hline & two-sided p-value & & \\
\hline & N & 438 & \\
\hline & Pearson correlation & 0.86 & 1.00 \\
\hline & two-sided p-value & 0.00 & 438 \\
\hline & N & 438 & 0.03 \\
\hline WEOTRADE & Pearson correlation & -0.04 & 0.42 \\
\hline & two-sided p-value & 396 & 396 \\
\hline & N & 0.33 & 0.25 \\
\hline WEOPRODUCT & Pearson correlation & 0.00 & 0.00 \\
\hline & two-sided p-value & 379 & 379 \\
\hline & N & 0.56 & 0.39 \\
\hline WEOLABOR & Pearson correlation & 0.00 & 0.00 \\
\hline & two-sided p-value & 376 & 376 \\
\hline & N & 0.22 & 0.27 \\
\hline WEOFINANCIAL & Pearson correlation & 0.00 & 0.00 \\
\hline & two-sided p-value & 396 & 396 \\
\hline & N & & \\
\hline
\end{tabular}

Relevant restrictions for regulatory equilibria need not in every case to be of an external nature. The existence of federal structures is an internal restriction which can have an impact on regulatory outcomes as well. Regions with certain fiscal or regulatory competencies might allow for elements of locational competition putting some pressure on inefficient regulatory burdens.

In order to test for the relevance of decentralized structures we make use of the data set on revenue decentralization provided by Stegarescu (2004). Compared to simple dummies for the existence of autonomous regions (as provided, for example by the World Bank Database on Political Institutions) these indicators offer the advantage to be of a continuous and, thus, more differentiated nature. Stegarescu offers a set of decentralization indicators based on the share of revenues assigned to regions. While Stegarescu's indicator “degree of revenue decentralization 3" (DRD3) simply measures the share of total government revenue assigned to the regions, the variable "degree of revenue decentralization 1" (DRD 1) only includes revenue sources over which sub-central governments possess significant control in the sense that they control at least the tax base or the tax rate. For countries like Germany with a large importance of shared taxes which cannot be autonomously controlled by the federal countries, DRD1 is considerably smaller than DRD3. It must be conceded that the aspect of tax autonomy is not identical to the aspect of regulatory autonomy. However, we simply employ the indicator as a proxy for federal autonomy in a more general sense. 
Table 2 depicts correlation coefficients among decentralization and regulation indicators. Both (highly correlated) decentralization indicators are positively and significantly correlated with the regulation indicators with the exception of trade regulation. This means that more centralized countries tend to have more regulated product, labour and financial markets.

\section{Specification and results}

In the following, a dynamic model for the path of deregulation is estimated. The specification follows the model developed by Abiad and Mody (2003) and applied by Helbling et al. (2004). It allows for the path of regulation to be driven by a steady convergence of regulation to some "optimum" level of regulation $R E G_{\mathrm{i}, \mathrm{t}}^{*}$. On the basis of the Stigler view at regulation this "optimum" should not be understood as a welfare maximizing solution but simply as the stable political-economic equilibrium level of regulation. In line with the definition of our regulatory indicators, larger levels of $R E G$ are associated with less restrictive regulatory regimes.

$$
\Delta R E G_{i, t}=\mu\left(R E G_{i, t}^{*}-R E G_{i, t-1}\right)+\varepsilon_{i, t}
$$

If the status quo bias is relevant the values of $\mu$ should be below 1 . This parameter of institutional stickiness is assumed to depend on the strictness of current regulation:

$$
\mu=k R E G_{i, t-1}
$$

Thus, this specification allows for learning following the arguments discussed in section 2: Deregulative steps can be helpful to limit uncertainty about the outcomes of deregulation.

Furthermore, this basic adjustment process is driven by further determinants including some element of yardstick competition where the distance to the regulatory situation of the benchmark group ( $R E G^{B M}$ ) has an impact on the country's deregulation path. This results in the following testable specification:

$$
\Delta R E G_{i, t}=\alpha_{1} R E G_{i, t-1}+\alpha_{2} R E G_{i, t-1}^{2}+\alpha_{3}\left(R E G_{i, t-1}^{B M}-R E G_{i, t-1}\right)+\sum_{k=1}^{K} \beta_{k} x_{k, i, t}+\varepsilon_{i, t}
$$

In (3) the coefficient $\alpha 3$ measures the impact of yardstick competition and the $\beta$ coefficients the influence of the further control variables including most of the above described globalization and decentralization variables. 
By construction, $\alpha_{1}=k^{*} R E G^{*}{ }_{i, t-1}$ and is expected to be positive, whereas $\alpha_{2}=-k$ would be negative if the status quo bias really loses power due to learning from deregulation. From this reduced form, the implicit "optimum" level of regulation equals $\alpha_{1} /\left(-\alpha_{2}\right)$.

For the estimation the following definitions and variables are used (see appendix for data sources):

For the benchmark level of regulation it is assumed that for European OECD countries the EU average is the relevant yardstick and the USA regulation level for other OECD countries. In this sense, our yardstick test is not one of mimicking the neighbours, but rather one of following more general international trends.

As proxies of crisis we make use of growth of real GDP and CPI inflation. We also experimented with unemployment which turned out to be mostly insignificant.

To control for the impact of the ideological orientation of government a dummy variable is constructed on the basis of the Database of Political Institutions (Beck et al., 2001) variable on the ideological orientation of chief executive's party. From the same database we also tested a number of indicators related to the stability of the government, ideological polarization in the parliament and the electoral cycle (election year dummy, years left in current term, change in government to measure the extent of "honeymoon effect"). However, these turned out to be largely insignificant and have therefore not been included in the presented final specifications.

Among the globalization indicators depicted in the descriptive analysis above, foreign population has to be dropped from the regressions due to too many missing values. Since the joint inclusion of the correlated indicators on trade and capital mobility would be confronted with multicollinearity problems, a principal component of the three series is calculated and employed as the baseline mobility variable (being negatively correlated to increasing levels of mobility).

With regard to the decentralization indicators, the final specification includes DRD3 which performed better than its alternatives from Stegarescu (2004).

Time and period fixed effects are included in the regressions depending on their joint significance. In order to limit problems of reversed causation (particularly relevant for trade and capital mobility) sensitive explanatory variables are lagged by one year. For the coefficient tests, White covariances are used which are robust to variances differing among cross-sections and periods.

Fixed effects estimations including the lagged dependent variable among the regressors face a problem of biased coefficients. The error term is correlated with the transformed values of the lagged dependent variable where each cross section's av- 
erage is subtracted from each observation. Microeconometric regressions where $\mathrm{T}$ is normally small deal with this difficulty by applying GMM-techniques along the lines suggested by Arellano and Bond (1991). However, Attanasio et al. (2000) have shown that an uncritical application is not always the best solution for country panels with a sufficiently large T. The problem is that instrumental-variable GMM approaches tend to produce imprecise estimates. Thus, there is a trade-off between the lack of precision with GMM estimates and the bias associated with the OLS approach. Attanasio et al. (2000) recommend to opt for the OLS approach "when T is big enough". The length of our time series dimension (up to 27 years are included for some countries) hints towards a bias of only a limited scale and, hence, favours the straight regression option which is applied in the following.

Tables 3 to 6 summarize the regression results. The estimation period is 1975 up to 2001 with relatively few observations in the years 2000 and 2001. There are substantial differences in dynamics between regulation fields. Deregulation appears to be self-enforcing in the case of financial and product market deregulation. Here, learning about deregulation's consequences after first deregulation steps, obviously helps to overcome resistance towards further dismantling of restrictions. For both fields, the speed of deregulation follows a reversed U-shape: Initially, learning effects speed up the process whereas later the closing gap towards the preferred level reduces the speed until the regulatory level has reached its equilibrium. The pattern for trade deregulation is different: it is characterized by classical steady convergence where an initial situation of high regulation tends to be followed by large deregulation steps. In contrast to that, labour markets do not show a stable dynamic pattern across different specifications.

Following the regulatory politics of the benchmark country (USA for nonEuropeans) or country group (EU for Europeans) is a significant and robust feature of deregulation in the case of financial and product markets. Cross-border links of regulatory politics are not significant for labour markets. In the case of trade, the equally significant and robust variable has the wrong sign (dropping the period fixed effects characterizing the trade regressions would leave the yardstick term insignificant).

Turning now to the indicators linked to mobility, some different specifications are presented. Whereas the baseline specification (1) makes use of the summarizing principal component of trade and capital mobility, specifications (2)-(4) look separately at each dimension. For financial markets and product markets there are significant results with the expected sign for FDI (which in the case of financial regulation also results in a significant principal component). The specific impact of FDI supports the argument from the theory of interest groups that national producer lobbies lose political influence by the entry of foreign companies with the consequence that large FDI speed up deregulation. 
Whereas neither trade openness nor capital mobility are significant drivers of trade deregulation there is an interesting significance of trade openness in the labour market regression: Larger trade openness is linked to more regulated labour markets.

Decentralization is a significantly positive driver of deregulation in the case of financial and labour markets but insignificant in the other cases. Not surprisingly due to the construction of the internal market in the period under consideration, EU member countries show a significantly larger speed of trade liberalization compared to other OECD countries.

Further insights from the regressions are as follows: There are hardly any signs on mutual reinforcements between the different fields of regulation (with the exception of a positive impact of labour on trade deregulation). Thus, learning from deregulation appears to be limited to the same regulatory field.

The crisis hypothesis is supported for financial deregulation and growth crises: low levels of growth increase the likelihood of deregulative action. Interestingly, bad inflation data are not helpful for creating preconditions for structural change: inflation is either insignificant or - as in the case of the financial market regressions - it has a negative sign. This is a result not unimportant for monetary policy: Allowing for high inflation rates does not appear to have the positive side-effect of speeding up deregulation. However, it should be added that this experience may be limited to the covered low inflation sample while cases of high inflation or even hyperinflation clearly contribute to a feeling of crisis and may then act as a deregulation catalyst.

Finally, ideology has a significant impact mainly in the case of labour market regulation. Here, significant differences exist between on the one hand left and right governments and on the other hand governments with a centre political orientation. Both left and right governments deregulate labour markets significantly more often than those associated with the political centre. 
Table 3: Panel estimation financial deregulation (dependent variable: change financial regulation indicator)

\begin{tabular}{|c|c|c|c|c|c|c|}
\hline & $(1)$ & $(2)$ & (3) & $(4)$ & $(5)$ & $(6)$ \\
\hline & \multicolumn{6}{|c|}{ convergence, learning and yardstick } \\
\hline level financial reg. $(-1)$ & $0.354 * * *$ & $0.367 * * *$ & $0.349 * * *$ & $0.355^{* * *}$ & $0.294 * * *$ & $0.360 * * *$ \\
\hline square of lagged level (-1) & $-0.405^{* * *}$ & $-0.402 * * *$ & $-0.403 * * *$ & $-0.396 * * *$ & $-0.318 * * *$ & $-0.406 * * *$ \\
\hline \multirow[t]{2}{*}{ yardstick (-1) } & $0.082 * *$ & $0.102 * * *$ & $0.081 * *$ & $0.096 * * *$ & $0.080 * *$ & $0.091 * *$ \\
\hline & \multicolumn{6}{|c|}{ trade and capital mobility } \\
\hline $\begin{array}{l}\text { mobility princip. compo- } \\
\text { nent }(-1)\end{array}$ & $-0.012 *$ & - & - & - & -0.008 & $-0.019 *$ \\
\hline trade $(-1)$ & - & 0.001 & - & - & - & - \\
\hline FDI $(-1)$ & - & - & $0.004 * * *$ & - & - & - \\
\hline \multirow[t]{2}{*}{ capital flows $(-1)$} & - & - & - & 0.000 & - & - \\
\hline & \multicolumn{6}{|c|}{ decentralization/EU } \\
\hline DRD3 & $0.002 * *$ & $0.002 *$ & $0.002 * *$ & $0.002 * *$ & $0.001^{* *}$ & $0.002 * *$ \\
\hline \multirow[t]{2}{*}{ EU dummy } & 0.014 & 0.011 & 0.014 & 0.016 & $0.027 *$ & 0.017 \\
\hline & \multicolumn{6}{|c|}{ regulatory interactions } \\
\hline level trade reg. $(-1)$ & - & - & - & - & -0.029 & - \\
\hline level product reg. (-1) & - & - & - & - & 0.002 & - \\
\hline level labour reg. (-1) & - & - & - & - & 0.033 & - \\
\hline \multirow[t]{2}{*}{ mean regulation $(-1)$} & - & - & - & - & - & -0.072 \\
\hline & \multicolumn{6}{|c|}{ crisis proxies } \\
\hline growth $(-1)$ & $-0.008 * * *$ & $-0.008 * * *$ & $-0.008 * * *$ & $-0.008 * * *$ & $-0.007 * * *$ & $-0.008 * * *$ \\
\hline \multirow[t]{2}{*}{ inflation (-1) } & $-0.005^{* *}$ & $-0.005^{* *}$ & $-0.005^{* *}$ & $-0.005^{* *}$ & $-0.003^{*}$ & $-0.005^{* *}$ \\
\hline & \multicolumn{6}{|c|}{ Ideology dummy (divergence from centre) } \\
\hline left $(-1)$ & 0.001 & -0.001 & 0.001 & 0.001 & $0.026 *$ & -0.001 \\
\hline right $(-1)$ & 0.006 & 0.000 & 0.007 & 0.001 & $0.029 * *$ & 0.001 \\
\hline included fixed effects & cross section & cross section & cross section & cross section & cross section & cross section \\
\hline nb. of observations & 371 & 387 & 371 & 383 & 361 & 361 \\
\hline R-squared & 0.24 & 0.24 & 0.24 & 0.24 & 0.18 & 0.24 \\
\hline
\end{tabular}


Table 4: Panel estimation product market deregulation (dependent variable: change product market regulation indicator)

\begin{tabular}{|c|c|c|c|c|c|c|}
\hline & (1) & (2) & (3) & (4) & (5) & (6) \\
\hline & \multicolumn{6}{|c|}{ convergence, learning and yardstick } \\
\hline level product reg. (-1) & $0.145^{* * *}$ & $0.152 * * *$ & $0.127 * * *$ & $0.145^{* * *}$ & $0.128 * *$ & $0.107 * *$ \\
\hline square of lagged level (-1) & $-0.101 * *$ & $-0.103 * *$ & $-0.092 *$ & $-0.105 * *$ & $-0.111^{*}$ & -0.080 \\
\hline \multirow[t]{2}{*}{ yardstick (-1) } & $0.148 * * *$ & $0.142 * * *$ & $0.141^{* * *}$ & $0.131 * * *$ & $0.116^{* *}$ & $0.116^{* * *}$ \\
\hline & \multicolumn{6}{|c|}{ trade and capital mobility } \\
\hline $\begin{array}{l}\text { mobility princip. compo- } \\
\text { nent }(-1)\end{array}$ & -0.003 & - & - & - & -0.004 & -0.004 \\
\hline trade $(-1)$ & - & -0.000 & - & - & - & - \\
\hline FDI $(-1)$ & - & - & $0.002 *$ & - & - & - \\
\hline \multirow[t]{2}{*}{ capital flows $(-1)$} & - & - & - & 0.000 & - & - \\
\hline & \multicolumn{6}{|c|}{ decentralization/EU } \\
\hline DRD3 & -0.000 & 0.000 & -0.000 & 0.000 & -0.050 & -0.000 \\
\hline \multirow[t]{2}{*}{ EU dummy } & 0.001 & 0.003 & 0.001 & 0.002 & 0.001 & 0.003 \\
\hline & \multicolumn{6}{|c|}{ regulatory interactions } \\
\hline level financial reg. (-1) & - & - & - & - & 0.009 & - \\
\hline level trade reg. $(-1)$ & - & - & - & - & 0.036 & - \\
\hline level labour reg. (-1) & - & - & - & - & 0.079 & - \\
\hline \multirow[t]{2}{*}{ mean regulation $(-1)$} & - & - & - & - & - & 0.038 \\
\hline & \multicolumn{6}{|c|}{ crisis proxies } \\
\hline growth $(-1)$ & -0.000 & 0.000 & -0.000 & -0.000 & 0.022 & 0.000 \\
\hline \multirow[t]{2}{*}{ inflation $(-1)$} & $-0.001 *$ & $-0.001 * *$ & $-0.001^{*}$ & $-0.001 *$ & -0.001 & -0.000 \\
\hline & \multicolumn{6}{|c|}{ ideology dummy (divergence from centre) } \\
\hline ideology dummy: left (-1) & -0.007 & -0.006 & -0.007 & -0.007 & -0.007 & -0.007 \\
\hline ideology dummy: right (-1) & -0.001 & -0.001 & -0.001 & -0.001 & -0.000 & -0.001 \\
\hline included fixed effects & cross section & cross section & cross section & cross section & cross section & cross section \\
\hline nb. of observations & 354 & 370 & 354 & 366 & 352 & 352 \\
\hline R-squared & 0.25 & 0.26 & 0.26 & 0.26 & 0.27 & 0.26 \\
\hline
\end{tabular}


Table 5: Panel estimation trade deregulation (dependent variable: change trade regulation indicator)

\begin{tabular}{|c|c|c|c|c|c|c|}
\hline & (1) & (2) & (3) & (4) & (5) & (6) \\
\hline & \multicolumn{6}{|c|}{ convergence, learning and yardstick } \\
\hline level trade reg. $(-1)$ & $-0.895 * *$ & $-0.880 * *$ & $-0.902 * *$ & $-0.886 * *$ & $-0.941^{* *}$ & $-0.916 * *$ \\
\hline square of lagged level $(-1)$ & -0.040 & -0.040 & -0.042 & -0.039 & -0.038 & -0.021 \\
\hline \multirow[t]{2}{*}{ yardstick $(-1)$} & $-0.803 * * *$ & $-0.788 * * *$ & $-0.809 * * *$ & $-0.793 * * *$ & $-0.838 * * *$ & $-0.806 * * *$ \\
\hline & \multicolumn{6}{|c|}{ trade and capital mobility } \\
\hline $\begin{array}{l}\text { mobility princip. compo- } \\
\text { nent (-1) }\end{array}$ & 0.002 & - & - & - & 0.004 & 0.001 \\
\hline trade $(-1)$ & - & -0.000 & - & - & - & - \\
\hline FDI $(-1)$ & - & - & -0.001 & - & - & - \\
\hline \multirow[t]{2}{*}{ capital flows $(-1)$} & - & - & - & 0.000 & - & - \\
\hline & \multicolumn{6}{|c|}{ decentralization/EU } \\
\hline DRD3 & -0.000 & -0.000 & -0.000 & -0.000 & $-0.000 *$ & -0.000 \\
\hline \multirow[t]{2}{*}{ EU dummy } & $0.018 *$ & $0.019 *$ & $0.019 *$ & $0.018^{*}$ & $0.018 *$ & $0.020 * *$ \\
\hline & \multicolumn{6}{|c|}{ regulatory interactions } \\
\hline level financial reg. (-1) & - & - & - & - & 0.006 & - \\
\hline level product reg. $(-1)$ & - & - & - & - & $-0.064 * *$ & - \\
\hline level labour reg. (-1) & - & - & - & - & $0.126 * *$ & - \\
\hline \multirow[t]{2}{*}{ mean regulation $(-1)$} & - & - & - & - & - & 0.006 \\
\hline & \multicolumn{6}{|c|}{ crisis proxies } \\
\hline growth $(-1)$ & -0.000 & -0.000 & -0.000 & -0.000 & -0.000 & -0.000 \\
\hline \multirow[t]{2}{*}{ inflation $(-1)$} & -0.001 & -0.001 & -0.001 & -0.001 & $-0.001 *$ & -0.001 \\
\hline & \multicolumn{6}{|c|}{ ideology dummies (divergence from centre) } \\
\hline ideology dummy: left (-1) & 0.001 & 0.000 & 0.001 & 0.000 & -0.001 & 0.001 \\
\hline ideology dummy: right (-1) & 0.003 & 0.003 & 0.003 & 0.003 & 0.002 & 0.004 \\
\hline included fixed effects & $\begin{array}{l}\text { cross sec- } \\
\text { tion/ period }\end{array}$ & $\begin{array}{l}\text { cross sec- } \\
\text { tion/ period }\end{array}$ & $\begin{array}{l}\text { cross sec- } \\
\text { tion/ period }\end{array}$ & $\begin{array}{l}\text { cross sec- } \\
\text { tion/ period }\end{array}$ & $\begin{array}{l}\text { cross sec- } \\
\text { tion/ period }\end{array}$ & $\begin{array}{l}\text { cross sec- } \\
\text { tion/ period }\end{array}$ \\
\hline nb. of observations & 371 & 387 & 371 & 383 & 361 & 361 \\
\hline R-squared & 0.33 & 0.33 & 0.33 & 0.33 & 0.36 & 0.34 \\
\hline
\end{tabular}


Table 6: Panel estimation labour market deregulation (dependent variable: change labour market regulation indicator)

\begin{tabular}{|c|c|c|c|c|c|c|}
\hline & (1) & (2) & (3) & (4) & (5) & (6) \\
\hline & \multicolumn{6}{|c|}{ convergence, learning and yardstick } \\
\hline level labour reg. $(-1)$ & -0.100 & $-0.302^{\star \star \star}$ & -0.104 & $-0.280^{* *}$ & -0.127 & -0.099 \\
\hline square of lagged level (-1) & -0.02 & $0.118^{*}$ & -0.069 & 0.118 & -0.081 & -0.057 \\
\hline \multirow{2}{*}{ yardstick (-1) } & -0.028 & $-0.077^{\star}$ & -0.027 & -0.060 & -0.074 & -0.007 \\
\hline & \multicolumn{6}{|c|}{ trade and capital mobility } \\
\hline $\begin{array}{l}\text { mobility princip. compo- } \\
\text { nent }(-1)\end{array}$ & 0.001 & - & - & - & 0.002 & 0.001 \\
\hline trade $(-1)$ & - & $-0.000^{\star \star}$ & - & - & - & - \\
\hline FDI $(-1)$ & - & - & 0.000 & - & - & - \\
\hline \multirow[t]{2}{*}{ capital flows $(-1)$} & - & - & - & -0.000 & - & - \\
\hline & \multicolumn{6}{|c|}{ decentralization/EU } \\
\hline DRD3 & $0.000^{\star *}$ & $0.000 * \star \star$ & $0.000 * \star \star$ & $0.000 * \star \star$ & $0.000 * \star \star$ & $0.000 * \star \star$ \\
\hline \multirow[t]{2}{*}{ EU dummy } & 0.004 & 0.004 & 0.005 & 0.003 & 0.004 & 0.004 \\
\hline & \multicolumn{6}{|c|}{ regulatory interactions } \\
\hline level financial reg. (-1) & - & - & - & - & 0.001 & - \\
\hline level trade reg. (-1) & - & - & - & - & -0.005 & - \\
\hline level product reg. $(-1)$ & - & - & - & - & 0.003 & - \\
\hline \multirow{2}{*}{ mean other regulation $(-1)$} & - & - & - & - & - & -0.012 \\
\hline & \multicolumn{6}{|c|}{ crisis proxies } \\
\hline growth $(-1)$ & 0.000 & $0.000^{*}$ & 0.000 & 0.000 & 0.000 & 0.000 \\
\hline \multirow[t]{2}{*}{ inflation $(-1)$} & $0.000^{\star *}$ & 0.000 & $0.000^{*}$ & -0.000 & 0.000 & 0.000 \\
\hline & \multicolumn{6}{|c|}{ ideology dummy (divergence from centre) } \\
\hline ideology dummy: left (-1) & $0.007^{\star \star}$ & 0.005 & $0.007^{* *}$ & 0.005 & 0.005 & $0.007^{\star *}$ \\
\hline ideology dummy: right (-1) & $0.011^{\star * *}$ & $0.009 * *$ & $0.011^{\star \star \star}$ & $0.009 * *$ & $0.009 * *$ & $0.010 * * \star$ \\
\hline fixed effects & $\begin{array}{l}\text { cross section } \\
\text { / period }\end{array}$ & cross section & $\begin{array}{l}\text { cross section } \\
\text { / period }\end{array}$ & cross section & cross section & $\begin{array}{l}\text { cross section } \\
\text { / period }\end{array}$ \\
\hline nb. of observations & 351 & 367 & 351 & 363 & 351 & 351 \\
\hline R-squared & 0.41 & 0.33 & 0.41 & 0.31 & 0.33 & 0.41 \\
\hline
\end{tabular}




\section{Conclusions}

The central question of this study asks for the regulatory leeway governments keep in the age of globalization. Our empirical study first of all shows that indeed the era of globalization is also a period of continuing (and converging) deregulation trends with regard to trade, financial and product markets of high-income industrial countries. At the same time, the econometric evidence shows that globalization in the narrow sense of trade openness and capital mobility has a rather limited impact as an immediate driver of deregulation. This means that national divergence from the global trends of deregulations is not clearly linked to the extent an economy is integrated in global capital, goods and services markets. Hence, in a narrow definition, globalization as such leaves substantial leeway for specific regulatory approaches of the nation state. However, in a wider sense globalization definitions also comprise the easier flow of knowledge and information across borders resulting in more effective cross-border learning processes. The evidence hints to the empirical relevance of these learning aspects of globalization at least on fields like product and financial markets. Obviously, yardstick competition is of relevance and governments commanding over instruments of regulative redistribution are not able to ignore deregulation processes beyond national borders.

The notable exception from these insights is labour market regulation. With regard to job protection regulation and the generosity of unemployment benefits neither deregulation nor convergence can be detected in the covered period. In addition, regulation trends on the labour markets are only poorly explainable by the logic of convergence or cross-border learning. At the same time, government ideologies have a relatively large impact. Furthermore, there is some evidence that labour market regulation proceeds with increasing trade openness. With regard to the latter result the findings do not allow to discriminate between Rodrik's compensation hypothesis and Vaubel's alternative explanation: Voters may demand higher levels of job protection and unemployment benefits because more structural change and job market turnover are the necessary outcome of globalization (Rodrik's view) or because globalization increases structural unemployment in countries with inflexible labour markets (Vaubel's view).

A further remarkable result is the catalyst role domestic decentralization appears to play for deregulation. This is a reminder about the continuing relevance of national constitutional structures for policy outcomes in a globalizing environment.

Some final caveats must be added: The detected deregulation trends on many fields may obscure the fact that on fields not covered by available indicators - e.g. social or environmental policies - regulation may be progressing. David Henderson raises this point correctly in his subsequent comment. Furthermore, our empirical evidence is based on the period between 1975 up to the end of last century. More recent intensification of locational competition resulting for example from the enlargement of the 
European Union towards Eastern Europe might have changed the situation since the nineties. Recent labour market reforms, e.g. in Germany, might hint to a new development that, finally, labour markets regulation has to adjust to the intensified international competition. However, it remains to be seen whether these single deregulation events result in a more general trend.

\section{References}

Abiad, Abdul and Ashoka Mody (2003): Financial Reform: What Shakes It? What Shapes It? IMF Working Paper, WP/03/70, Washington.

Arellano, Manuel and Stephen Bond (1991): Some Tests of Specification for Panel Data: Monte Carlo Evidence and an Application to Employment Equations, Review of Economic Studies, 58, 277-297.

Attanasio, Orazio P., Picci, Lucio and Antonelle E. Scorcu (2000): Saving, Growth, and Investment: A Macroeconomic Analysis Using a Panel of Countries, The Review of Economics and Statistics, 82 (2), 182-211.

Beck, Thorsten, George Clarke, Alberto Groff, Philip Keefer and Patrick Walsh: New Tools in Comparative Political Economcy: The Database of Political Institutions, The World Bank Economic Review, 15 (1), 165-176.

Besley, Timothy and Anne Case (1995): Incumbent Behavior: Vote-Seeking, TaxSetting, and Yardstick Competition, The American Economic Review, 85(1), 25-45.

Fernandez, Raquel and Dani Rodrik (1991): Resistance to Reform: Status Quo Bias in the Presence of Individual-Specific Uncertainty, American Economic Review, 81 (5), 1146-1155.

Heinemann, Friedrich (2004): Explaining Reform Deadlocks, Applied Economics Quarterly Supplement, 55, 9-26.

Helbling, Thomas, Dalia Hakura, and Xavier Debrun (2004): Fostering Structural Reforms in Industrial Countries, in: World Economic Outlook 2004, chapter III, 103-146.

Mueller, Dennis C. (1989): Public choice II, A revised edition of Public choice, Cambridge University Press.

Nickell, Stephen and Luca Nunziata: Labour Market Institutions Database, September 212001

Nicoletti and Scarpetta (2003): Regulation, Productivity, and Growth: OECD Evidence", Economic Policy, April 2003, 11-72..

Olson, Mancur (1965): The Logic of Collective Action, Harvard University Press. 
Pitlik, Hans and Steffen Wirth (2003): Do Crises Promote the Extent of Economic Liberalization?: an Empirical Test, European Journal of Political Economy, 19, 565-581.

Rodrik, Dani (1996): Understanding Economic Policy Reform, Journal of Economic Literature, 34 (March), 9-41.

Rodrik, Dani (1998): Why do more open economies have bigger governments? Journal of Political Economcy, 106 (5), 997-1032.

Samuelson, William and Richard Zeckhauser (1988): Status Quo Bias in Decision Making, Journal of Risk and Uncertainty, 1, 7-59.

Schulze, Günther G. and Heinrich W. Ursprung (1999): Globalisation of the Economy and the Nation State, The World Economy, 22 (3), 295-352.

Stegarescu, Dan (2004), Public Sector Decentralization: Measurement Concepts and Recent International Trends, ZEW Discussion Paper No. 04-74, Mannheim.

Vaubel, Roland (2000): Internationaler Politischer Wettbewerb: Eine europäische Wettbewerbsaufsicht für Regierungen und die empirische Evidenz, in: Schenk, Karl-Ernst et al. (Eds.): Jahrbuch für Neue Politische Ökonomie, 19, Globalisierung und Weltwirtschaft, Mohr Siebeck, 280-309.

Vaubel, Roland (2005, forthcoming): Sozialpolitische Konsequenzen der Globalisierung, Theorie und Empirie, in: Andreas Freytag (Ed.): Weltwirtschaftlicher Strukturwandel, nationale Wirtschaftspolitik und politische Rationalität, Universitätsverlag. 


\section{Appendix: Data Sources}

\begin{tabular}{|c|c|c|}
\hline time series & description & source \\
\hline WEOFINANCIAL & $\begin{array}{l}\text { index financial sector regulation, details } \\
\text { see text section } 3\end{array}$ & Helbling et al. (2004) \\
\hline WEOLABOR & $\begin{array}{l}\text { index labor market regulation, details see } \\
\text { text section } 3\end{array}$ & Helbling et al. (2004) \\
\hline WEOPRODUCT & $\begin{array}{l}\text { index product market regulation, details } \\
\text { see text section } 3\end{array}$ & Helbling et al. (2004) \\
\hline WEOTRADE & $\begin{array}{l}\text { index trade liberalization, details see text } \\
\text { section } 3\end{array}$ & Helbling et al. (2004) \\
\hline DRD1 & share of revenue assigned to regions & Stegarescu (2004) \\
\hline DRD3 & share of revenue under control of regions & Stegarescu (2004) \\
\hline growth & GDP growth & $\begin{array}{l}\text { World Bank: World Devel- } \\
\text { opment Indicators }\end{array}$ \\
\hline inflation & inflation, consumer prices & $\begin{array}{l}\text { World Bank: World Devel- } \\
\text { opment Indicators }\end{array}$ \\
\hline FDI & gross foreign direct investment in \% GDP & $\begin{array}{l}\text { World Bank: World Devel- } \\
\text { opment Indicators }\end{array}$ \\
\hline trade & $\begin{array}{l}\text { sum of exports and imports of goods and } \\
\text { services (in \% GDP) }\end{array}$ & $\begin{array}{l}\text { World Bank: World Devel- } \\
\text { opment Indicators }\end{array}$ \\
\hline capital flows & $\begin{array}{l}\text { sum of the absolute values of direct, port- } \\
\text { folio, and other investment inflows and } \\
\text { outflows recorded in the balance of pay- } \\
\text { ments financial account, excluding changes } \\
\text { in the assets and liabilities of monetary } \\
\text { authorities and general government (in \% } \\
\text { GDP). }\end{array}$ & $\begin{array}{l}\text { World Bank: World Devel- } \\
\text { opment Indicators }\end{array}$ \\
\hline foreign population & foreign population (in \%) & $\begin{array}{l}\text { World Bank: World Devel- } \\
\text { opment Indicators }\end{array}$ \\
\hline ideology dummy: left & $\begin{array}{l}\text { generated from chief executive’s party } \\
\text { ideology variable }\end{array}$ & Beck et al. (2001) \\
\hline $\begin{array}{l}\text { ideology dummy: } \\
\text { right }\end{array}$ & $\begin{array}{l}\text { generated from chief executive's party } \\
\text { ideology variable }\end{array}$ & Beck et al. (2001) \\
\hline eumember & dummy for EU membership & \\
\hline
\end{tabular}

